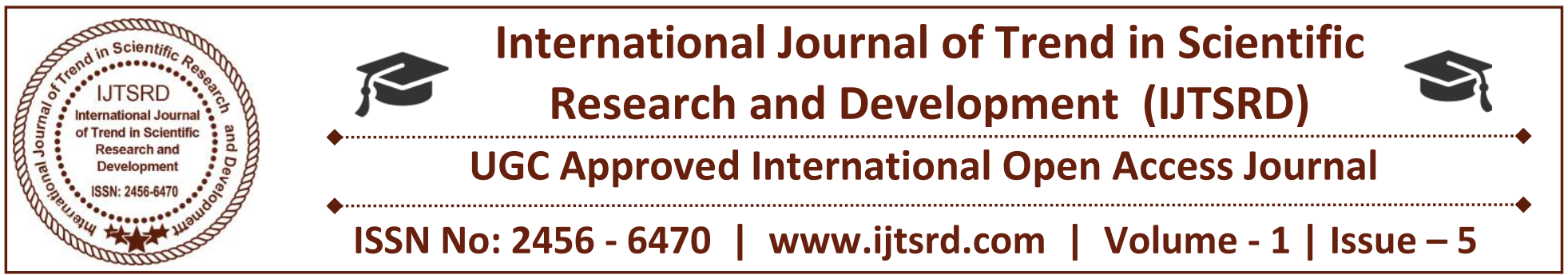

\title{
Green Plastics: Poly-lactic Acid Synthesis from Waste Tamarind Seed Powder \& its Applications
}

\author{
Dr. R. P. Ugawekar \\ Associate Professor, \\ Laxminarayan Institute of \\ Technology, RTMNU, Nagpur
}

\author{
Payal N. Bhautik \\ Ph.D. Scholar, \\ Laxminarayan Institute of \\ Technology, RTMNU, Nagpur
}

\author{
Kuldeep Singh \\ M.Sc. Chemistry, \\ Dr. C.V. Raman University, \\ Nagpur
}

\begin{abstract}
In the era of sustainable development there is a necessity to produce biodegradable polymers to minimize the soil pollution. With the need of the hour Green plastic is the polymeric material formulated for specific applications, which is derived from the Tamarind seed de-oiled cake starch. Through the series of unit operations, starch which is produced can be fermented by Lactobacillus delbrueckii, Lactobacillus amylophylus and Lactobacillus amylovirus. The polymerization reaction of Lactic Acid is carried out by using a catalyst. To cope up with the scarcity of valuable petroleum product \& to minimize the environmental pollution, Green plastic materials play an important role for sustainable development.
\end{abstract}

Keywords: Poly lactic acid, Green Plastics, Biodegradable polymers, Waste Tamarind seed de-oiled cake starch

\section{INTRODUCTION}

The term green plastic is applied to any polymeric material derived from a source of natural origin or purely synthetic, process-able like conventional thermoplastics on existing equipments to finished product which are completely degradable either of the action of water or microbes. The term green plastic therefore applies strictly to the wholly degradable resins i.e. material with the degradable polymer as the matrix and not to the product containing $6 \%$ starch. They are $100 \%$ biodegradable for example starch, lignin, cellulose etc.

Green plastics are completely biodegradable by microorganisms or by water. Polymers which are mostly used today are not completely biodegradable, where the polymer may contain certain substituent which is biodegradable. For example in a polyethylene compound loading with $5 \%$ starch, only starch component is biodegradable while polyethylene is not, since the polymers are mainly petroleum base which are not completely biodegradable. So there is a chance of pollution problem and also a chance of oil depletion. To avoid such a problem, the development of green plastics is important. Though the advancements, developments and modifications were done with polymers, still they are the major cause of the environmental pollution even after disposal ${ }^{10}$.

\section{Need of Green Plastic}

To protect environment and human being from threats caused by accumulation of plastic waste.

$>$ To serve the natural resource because generally the plastic is derived from the hydrocarbons. 
To reduce the release of toxic substances as compare to other polymer materials.

To conserve the use of virgin polymers.

Need for reduction in use of fossil fuel feedstock \& increase in use of renewable feedstock, thus reducing the pollution. This can be achieved by biodegradable plastic. Biodegradable plastic are those plastic when disposed into biologically active environment are converted into smaller molecules that are not harmful to the environment. Starch based biodegradable plastics are those which are easily attacked by soil micro-organisms which breaks the polymer chain $\&$ becomes the part of plastic ${ }^{10}$.

\section{Natural Polymers}

Almost all plastic today are made from synthetic polymers. There are however, polymers that occur in nature, biopolymers. Carbohydrates and proteins, for example are biopolymers. Many biopolymers are already being produce commercially on large scale. They are available to be used in the production of plastic.

Starch is found in waste Tamarind seed as well as in maize, potato, wheat and some other plants. Annual production of starch is well over 70 billion pound, with much of it being used for food and non-food purposes like making paper, cardboards, textile sizing and adhesives.

Collagen is the most abundant protein found in mammals. Gelatin is denature collagen and is used in sausage casing, capsules for drugs and vitamin preparation and other miscellaneous industrial applications including photography. Casein commercially produced mainly from cow's skimmed milk. It is used in adhesives, binders, protective coatings and other products. Proteins (from waste Tamarind seed de-oiled cake) are abundant plant proteins basically tamarind seed de-oiled cake directly is use for making adhesives, coating for paper and cardboard ${ }^{10}$.

\section{Market Data of Waste Tamarind seed}

Tamarind has been described as one of the common and most important trees of India. India is the world's top producer, exporting several thousands of tones of seed, seed de-oiled cake and fruit pulp each year. Tamarind trees are often grown in gardens and along roadsides and are cultivated commercially in plantations. India is the only producer of tamarind on a commercial scale. A large part of India's production of tamarind is exported to West Asia, Europe and America, where it is used for food specialties like Worcestershire sauce. This spice also comes in the forms of pulp and juice concentrates which mainly go into the preparation of cool drinks, sea foods and a range of sophisticated cuisine. Tamarind is native to tropical America and this plant is widely seen throughout Asia and it has acquired the common name Aasam, meaning, simply, 'acid' as they are used as acid flavors in the food Industry. Tamarind cultivars are divided into two basic categories: sweet and sour. India mainly grows sour cultivars in orchard-like plantations. Tamarind is widely used throughout the world. Tamarind pulp concentrate is widely used in Indian and Middle Eastern cooking.

Tamarind can be found in various forms like concentrated pulp with seeds, a canned paste, whole dried pods, or de-oiled cakeed. It is available in Indian and some other Asian markets. There is a wide variety of tamarind products available in the market for consumption. They include tamarind paste, seedless dried tamarind, tamarind pods, tamarind concentrate, tamarind syrup, tamarind drink concentrate, tamarind sauce, tamarind chutney, tamarind dipping sauce, tamarind gelatin, tamarind candy etc. Tamarind may also be used as a base for delicious raw or cooked chutneys, its fruity acidity combining well with sugar, chilli and other flavours. Moreover tamarind concentrates are extensively used as an ingredient and an effective substitute for vinegar, tomatoes and lemon juice.

Tamarind, an essential ingredient in the South Indian cuisine and a host of processed food items across the globe, can also offer livelihood security in rural and tribal areas, experts indicate. Its organized processing, supported by cold storage facilities, is found to be ideal for ensuring market price stability and rural employment. India is the largest producer and exporter of range of raw and processed spices. Processed spices demand is directly linked with its consumption in food processing industry and this is set to grow in India in coming period with growth of population and fast changing food habits as well as increase in spending power of the middle and upper class in India.

Why waste Tamarind seed de-oiled cake: The composition of waste Tamarind seed de-oiled cake 
which is full of carbohydrates, protein, oil, minerals and others. The waste Tamarind seed de-oiled cake possesses starch of about $51.0 \%$ and after de-oiling of the tamarind seeds the starch contain becomes $55.0 \%$ which can be used for the production of green plastic. We need starch for production of PLA. Therefore we used waste Tamarind seed i.e. de-oiled tamarind deoiled cake because it is enrich of $\operatorname{starch}^{4}$.

\begin{tabular}{|l|l|l|}
\hline Composition & Original & De-oiled \\
\hline Oil & $7.6 \%$ & $0.6 \%$ \\
\hline Protein & $7.6 \%$ & $19.0 \%$ \\
\hline Polysaccharide & $51.0 \%$ & $55.0 \%$ \\
\hline Crude Fibre & $1.2 \%$ & $1.1 \%$ \\
\hline Total Ash & $3.9 \%$ & $3.4 \%$ \\
\hline $\begin{array}{l}\text { Acid Insoluble } \\
\text { Ash }\end{array}$ & $0.4 \%$ & $0.3 \%$ \\
\hline Moisture & $7.1 \%$ & \\
\hline
\end{tabular}

Natural Process in plants body by Photosynthesis LA (Lactic Acid) to PLA

1. Carbon dioxide enters the pores.

2. Veins supply water to cell.

3. Solar energy entraps in chloroplast for photosynthesis.

4. Chloroplast produces sugar and oxygen. Sugar is used as fuel.

5. Unused sugar is send to kernel \& stored as starch.

6. Carbon Dioxide when reacts with water in the presence of Sunlight gives Glucose with small amount of Oxygen released.

7. Micro-organisms convert starch to lactic acid.

8. Lactic acid molecules link together to form rings called lactide monomer.

9. These ring opens and polymerization of lactide monomer takes place resulting in formation of PLA.

\section{Process for manufacturing Green Polymer}

In the processing of green plastics, tamarind must be grown, harvest and transported to processers where seeds are removed and remaining part is used for pulp making and concentrate making. But we have to required only seeds for production of oil and then that de-oiled tamarind seeds de-oiled cake is used for glucose extracted and fermented into cell containing PHA Phytohaemagglutinin (lectin),. The cell are washed, spun in a centrifuge and broken apart to release the PHA Phytohaemagglutinin (lectin), which is again washed and centrifuge.
Conversion of Waste Tamarind seed de-oiled cake to Plastic

There are various steps involved in the conversion of waste Tamarind seed de-oiled cake to starch.

\section{Cleaning}

The raw material is delivered in de-oiled tamarind seeds cleaning machine. The waste Tamarind seed is inspected and cob, dust, chaff and foreign material are removed. After cleaning the waste de-oiled Tamarind seed is transported to the sun drying.

\section{Drying}

A proper drying is essential for high yields and high starch quality. This is carried out to reduce the moisture content in seeds. It is necessary in order to avoid damage of seeds by micro organisms and for storing seeds for a long span of time. Drying is to be done to such a extent, so that it becomes very easy to grind.

\section{Grinding and Screening}

After germ separation the material of waste Tamarind seed de-oiled cake (germ) is transported to the grinding mill to release starch \& glucose bond in the form of fiber. The ground tamarind seeds are then screened to obtain the desired size $(.825, .412$, $.300 \mathrm{~mm})$.

\section{Inoculation of micro organisms:}

Inoculum is prepared by sterile water $\mathrm{NaCl}$ solution and pre-cultured microorganisms. The $\mathrm{pH}$ is maintained at 8.2 to 8.8 and initially nutrients (pectin de-oiled cake, Glucose-D) are provided to the inoculums for the initial growth of microorganism. Whole solid state fermentation is carried out in closed fermentor at 36 to $38^{\circ} \mathrm{C}^{10}$.

\section{Enzymes Used for Fermentation:}

The desirable characteristics of industrial microorganisms are their ability to rapidly and completely ferment cheap raw materials, requiring minimal amount of nitrogenous substances, providing high yields of preferred stereo specific lactic acid under conditions of low $\mathrm{pH}$ and high temperature. The choice of an organism primarily depends on the carbohydrate to be fermented. Lactobacillus delbrueckii, Lactobacillus amylophylus and actobacillus amylovirus are able to ferment $\operatorname{starch}^{4,7,8}$.

\section{Starch Fermentation}

To convert Waste Tamarind seed de-oiled cake Starch into Lactic Acid, Solid state Fermentation process is used. In this process, the Waste Tamarind seed de- 
International Journal of Trend in Scientific Research and Development (IJTSRD) ISSN: 2456-6470

oiled cake Starch is fermented with the help of Lactobacillus delbrueckii, Lactobacillus amylophylus and actobacillus amylovirus Enzymes to produce Lactic Acid ${ }^{7}$.

\section{Lactic acid Properties}

Physical and Chemical properties of lactic acid

\begin{tabular}{|c|c|}
\hline Chemical formula & $\mathrm{C}_{3} \mathrm{H}_{6} \mathrm{O}_{3}$ \\
\hline Chemical name & $\begin{array}{l}\text { (S)-2-hydroxy- } \\
\text { propanoic acid }\end{array}$ \\
\hline Molecular Weight & 90.08 \\
\hline Physical appearance & $\begin{array}{l}\text { aqueous } \\
\text { solution }\end{array}$ \\
\hline Taste & mild acid taste \\
\hline Melting point & $53^{\circ} \mathrm{C} / 127^{\circ} \mathrm{F}$ \\
\hline Boiling point & $\begin{array}{c}>200^{\circ} \mathrm{C} / \\
390^{\circ} \mathrm{F}\end{array}$ \\
\hline $\begin{array}{l}\text { Solubility in water (g/100 } \\
\text { g H2O) }\end{array}$ & Miscible \\
\hline Dissociation Constant, Ka & $1.38 * 10^{\wedge}-4$ \\
\hline pKa & 3.86 \\
\hline pH $\left(0.1 \%\right.$ solution, $\left.2^{\circ} \mathrm{C}\right)$ & 2.9 \\
\hline pH $\left(0.1 \mathrm{~N}\right.$ solution, $\left.2^{\circ} \mathrm{C}\right)$ & 2.4 \\
\hline
\end{tabular}

\section{Polymerization ${ }^{1}$}

Then the polymerization is carried out using conventional polymerization techniques.

1) Bulk polymerization

2) Suspension polymerization

3) Emulsion polymerization

4) Solution polymerization

\begin{tabular}{|l|l|l|}
\hline $\begin{array}{l}\text { Sr. } \\
\text { No. }\end{array}$ & \multicolumn{2}{|l|}{ Lactic acid Structure } \\
\hline $\mathbf{1}$ & L-lactic Acid & D-lactic Acid \\
\hline $\mathbf{2}$ & & \\
\hline
\end{tabular}

\section{Polymerization of Lactide}

Polylactides (PLAs) :-

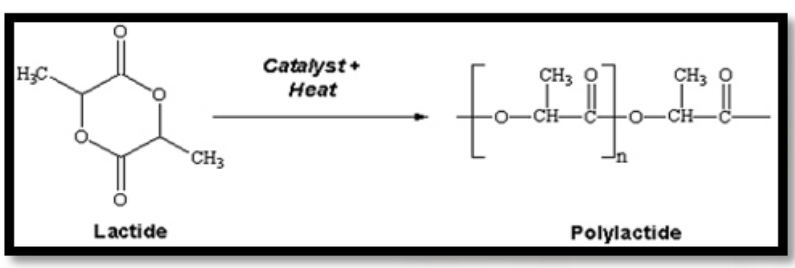

$>$ PLA can be easily produced through ringopening polymerization of lactide using a (stannous octoate) catalyst.

$>$ Good moisture-barrier properties.

$>$ It is able to withstand the rigors of injection molding and blow or vacuum-forming processes.

\section{Degradation}

Degradation is the process by which deteriorate ion in the properties occur due to reduction in molecular weight.

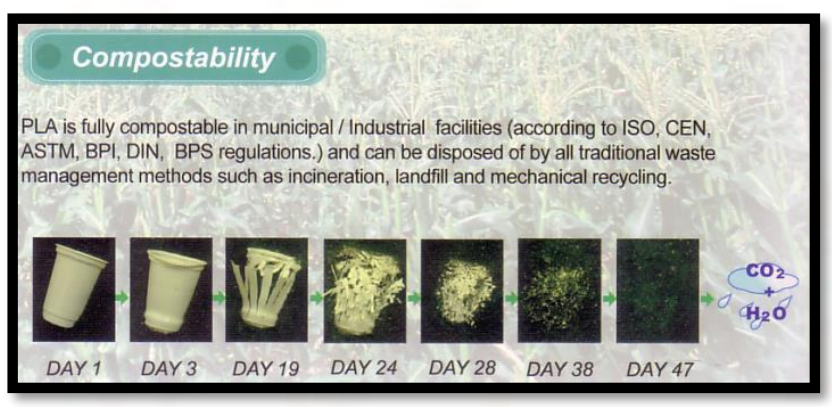

The above image shows the degradation of disposal glass made from green plastic and how it get decompose when it goes to the land filling. Life Span of the biodegradable plastic is up to 60 days and it can be increase by the sizing of the that polymer by means of shellac coating up to 1 year ${ }^{10}$. 


\section{Distinguish between synthetic plastic and green plastic:}

\begin{tabular}{|c|c|c|}
\hline $\begin{array}{l}\text { Sr. } \\
\text { No. }\end{array}$ & Synthetic Plastics & Green Plastics \\
\hline 1. & $\begin{array}{l}\text { Plastic is a material that contain as an } \\
\text { essential ingredient one or more polymer } \\
\text { substance. }\end{array}$ & $\begin{array}{l}\text { It is naturally occurring plastics made } \\
\text { from plants. }\end{array}$ \\
\hline 2. & $\begin{array}{l}\text { The cost of synthetic plastic is lower } \\
\text { than green plastic. }\end{array}$ & $\begin{array}{l}\text { The cost of green plastic is much more } \\
\text { than synthetic plastic. }\end{array}$ \\
\hline 3. & It is non renewable. & It is renewable. \\
\hline 4. & It is non biodegradable. & It is biodegradable. \\
\hline 5. & $\begin{array}{l}\text { It is made from non renewable resources } \\
\text { like petroleum, natural gas and coal } \\
\text { which are exiting. }\end{array}$ & $\begin{array}{l}\text { It is made from renewable sources like } \\
\text { plant which are easily available. }\end{array}$ \\
\hline 6. & It is easily available & It is not easily available. \\
\hline
\end{tabular}

\section{Processing Parameters of Green Plastic}

There are two main types to bear in mind when processing green plastics:-

The limited thermal stability of the polymer, the polymer degrading rapidly above $195^{\circ} \mathrm{C}$.

$>$ The need to optimize conditions to allow a maximum rate of crystallization and thus reduce cycle time. The maximum rate of crystallization is reported to be at about $55-60^{\circ} \mathrm{C}$.

$>$ Processing temperature should not exceed $180^{\circ} \mathrm{C}$.

$>$ Duration of time the material is in the melt state should be kept to a minimum when blow molding the blow pin and mould should be at about $60^{\circ} \mathrm{C}$ to optimize crystallization state. Similarly injection moulds are recommended to be held at 60 or 65 degree Celsius.

\section{Properties of Green Plastics}

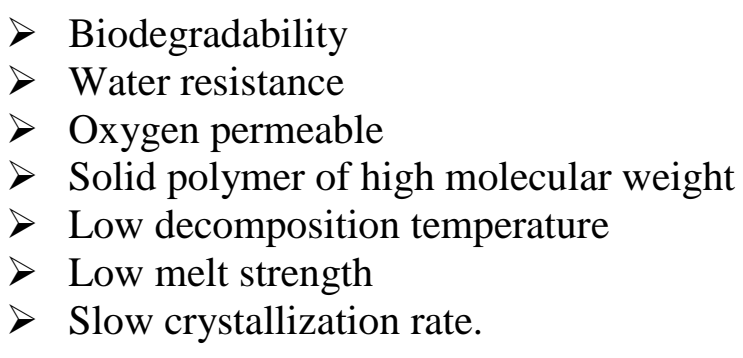

\section{Applications of Green Plastics}

There are various applications of green plastics are as follows:-
It is mostly used in packaging for product such as shampoos and cosmetics.

$>$ It is used for manufacturing disposable products used in the food industry.

Plastic wrap for packaging.

$>$ Used to produce bottles.

$>$ Moisture barrier films for hygienic products.

$>$ Coating for paper, cardboard, etc.

$>$ It is used in agricultural applications.

$>$ It is used for coating drugs.

\section{Advantages of Green Plastics:}

$>$ High resistance to the effect of atmosphere.

$>$ Easily possible to being processed into complex shape.

$>$ It is light in weight for easy transportation.

$>$ Because of low thermal and electrical conductance it is used as thermal and electrical insulators.

$>$ It is not attacked by fungi, insects, etc.

$>$ Green plastics are biodegradable.

$>$ It is environmental.

$>$ Green plastics are transparent as well as translucent.

$>$ It has low maintenance cost.

\section{Disadvantages of Green Plastics}

$>$ Cost of green plastic is very high as compare to synthetic plastic.

$>$ Energy required for green plastic is more than synthetic plastic.

After disposal of green plastic it produces green house gases. 


\section{CONCLUSION}

The abundant availability of naturally occurring polymers is of great technical importance in industrial basis on environment point of view as far as biodegradability is concerned. Green plastic materials play vital role in deciding the cost factor of the compound. Taking a sustainability factor into account, disposal and environmental problems can be greatly reduced by the use of green plastic end products for specific applications. Apart from that use of green plastic will provide a solution on the deficiency of the petro-product or the rock oil is concerned. Bioplastic gets decomposed in maximum 60 days and produces water and the green house gas $\left(\mathrm{CO}_{2}\right)$. Degradation of bio-plastic carried out in the digester by giving the appropriate condition such as temperature and this Carbon Dioxide can be recovered and store from the digester in this way we can resolve the problem of evolution of $\mathrm{CO}_{2}$ in the environment. The life span of the bio-plastic can be increases up to12 months by sizing and coating.

\section{REFERENCES}

1. A. Bakibaeva, A.M. Gazalievb, S.K. Kabievab, V.I. Fedorchenkob, G.Ya. Gubaa, E.I. Smetaninaa*, I.R. Dolgova, R.O. Gulyaeva 16th International Scientific Conference "Chemistry and Chemical Engineering in XXI century dedicated to Professor L.P. Kulyov, CCE 2015 Polymerization of Lactic Acid Using Microwave and Conventional Heating.

2. Badal C. Saha,1 Lawrence K. Nakamura2 Production of Mannitol and Lactic Acid by Fermentation With Lactobacillus intermedius NRRL B-3693†.

3. Emmy De Caluwé (1), Kateřina Halamová (2),Patrick Van Damme (1) afrika focus Volume 23, Nr. 1, 2010 - pp. 53-83 Tamarindus indica L. - A review of traditional uses, phytochemistry and pharmacology.

4. J H Litchfield, Battelle Memorial Institute, Columbus, OH, USA, 2009 Lactic Acid, Microbially Produced.

5. Jharna Bansal, Nitin Kumar, Rishabha Malviya and Pramod Kumar Sharma American-Eurasian Journal of Scientific Research 9 (1): 01-05, 2014, ISSN 1818-6785, Extraction and Evaluation of Tamarind Seed Polysaccharide as Pharmaceutical In situ Gel Forming System.
6. Kyoto Institute of Technology, Japan.,2014, PLA Synthesis. From the Monomer to the Polymer.

7. L. F. Coelho1, C. J. B. de Lima1, C. M. Rodovalho2, M. P. Bernardo1 and J. Contiero1* LACTIC ACID PRODUCTION BY NEW Lactobacillus plantarum LMISM6 GROWN IN MOLASSES: OPTIMIZATION OF MEDIUM COMPOSITION.

8. Milena S. Lopes*, André L. Jardini and Rubens M. Filho.2016, Synthesis and Characterizations of Poly (Lactic Acid) by Ring-Opening Polymerization for Biomedical Applications

9. Mortadha A. Ali 1,*, Tahseen A. Al-Hattab 1, Imad A. Al-Hydary 2. International Journal of Advances in Engineering \& Technology, June, 2015. EXTRACTION OF DATE PALM SEED OIL (PHOENIX DACTYLIFERA) BY SOXHLET APPARATUS.

10. Miss. Payal N Bhautik, 2017, Studies on manufacturing processes of tamarind oil, biodegradable plastic and related products from tamarind- A review, 75-80.

11. Tayyba Ghaffar a, Muhammad Irshad a,*, Zahid Anwar a, Tahir Aqil b, Zubia Zulifqar a, Asma Tariq a, Muhammad Kamran a, Nudrat Ehsan a, Sajid Mehmood a Recent trends in lactic acid biotechnology: A brief review on production to purification.

12. Yebo Li and Fengjie Cui, 2009,Microbial Lactic Acid Production from Renewable Resources

13. Young-Jung Wee1, Jin-Nam Kim2 and Hwa-Won Ryu1_Biotechnological Production of Lactic Acid and Its Recent Applications

14. Yunzi Hu 1, Walid A. Daoud 1, Kevin Ka Leung Cheuk 2 and Carol Sze Ki Lin 1,*2016, Newly Developed Techniques on Polycondensation, Ring-Opening Polymerization and Polymer Modification: Focus on Poly(Lactic Acid).

15. Zulfiqar Ali*, Faqir Muhammad Anjum and Tahir Zahoor, Kazunari Masutani and Yoshiharu Kimura*2006 Production of lactic acid from corn cobs hydrolysate through fermentation by Lactobaccillus delbrukii. 